\title{
Correction to: Synchronization in 5G networks: a hybrid Bayesian approach toward clock offset/skew estimation and its impact on localization
}

Meysam Goodarzi ${ }^{1,2^{*}}$, Darko Cvetkovski ${ }^{1,2}$, Nebojsa Maletic ${ }^{1}$, Jesús Gutiérrez ${ }^{1}$ and Eckhard Grass ${ }^{1,2}$

The original article can be found online at https://doi. org/10.1186/s13638-021 01963-x.

\section{*Correspondence:}

goodarzm@hu-berlin.de

${ }^{1}$ IHP - Leibniz-Institute Für

Innovative Mikroelektronik, Frankfurt (Oder), Germany Full list of author information is available at the end of the article

\section{Correction to: J Wireless Com Network (2021) 2021:91 https://doi.org/10.1186/s13638-021-01963-x}

Following publication of the original article [1], the authors flagged that their article had been published with incorrect versions of Figs. 6, 9, 10 and 11.

The original article has since been updated with the corrected figures, and the figures may be found in this correction for reference.

The authors apologize for any inconvenience caused.

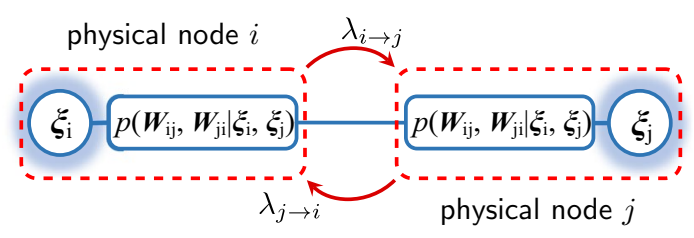

Fig. $6 \lambda_{i \rightarrow j}=\lambda_{p_{i j} \rightarrow \boldsymbol{\xi}_{j}}$ and $\lambda_{j \rightarrow i}=\lambda_{p_{i j} \rightarrow \boldsymbol{\xi}_{i}}$ are the BP messages exchanged between physical nodes in practice
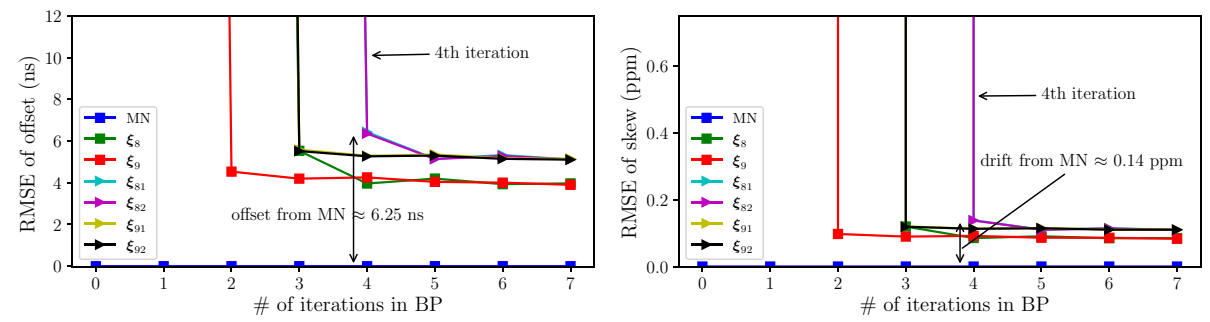

Fig. 9 BP applied on the whole network author(s) and the source, provide a link to the Creative Commons licence, and indicate if changes were made. The images or other third party material in this article are included in the article's Creative Commons licence, unless indicated otherwise in a credit line to the material. If material is not included in the article's Creative Commons licence and your intended use is not permitted by statutory regulation or exceeds the permitted use, you will need to obtain permission directly from the copyright holder. To view a copy of this licence, visit http:// creativecommons.org/licenses/by/4.0/. 

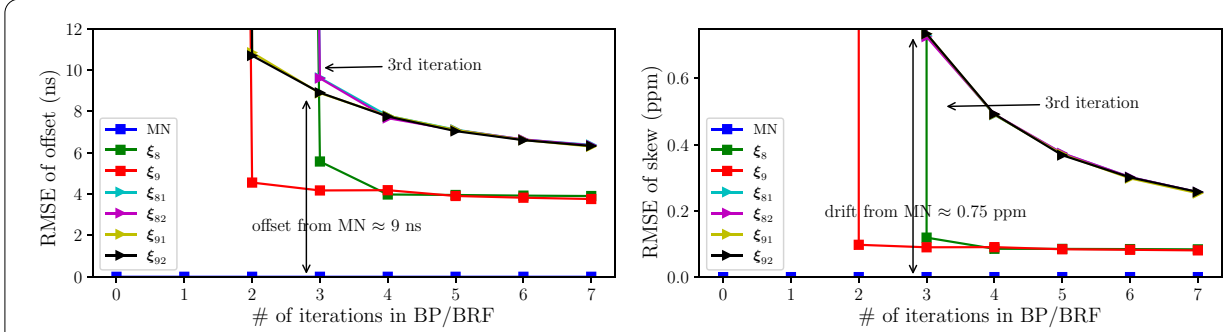

Fig. 10 BP and BRF applied to the network in a hybrid manner
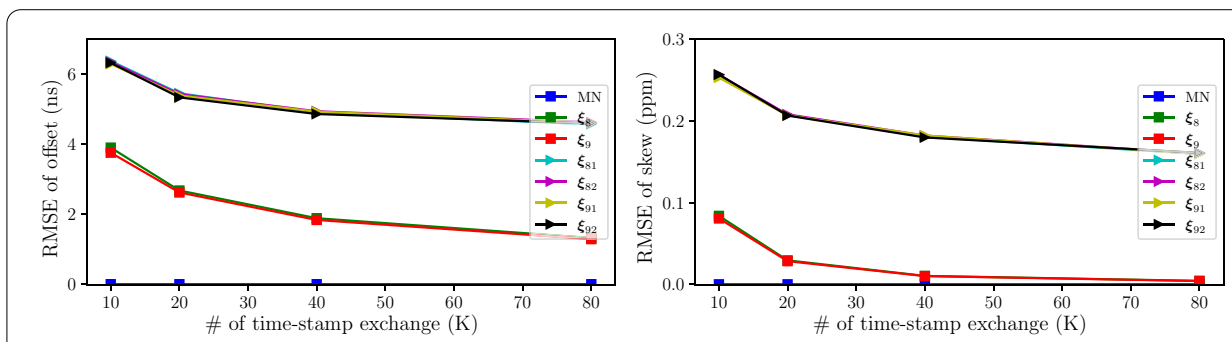

Fig. 11 Impact of number of time-stamp exchanges $K$

\section{Author details}

${ }^{1}$ IHP - Leibniz-Institute Für Innovative Mikroelektronik, Frankfurt (Oder), Germany. ${ }^{2}$ Humboldt University of Berlin, Berlin, Germany.

Published online: 02 November 2021

\section{Reference}

1. M. Goodarzi, D. Cvetkovski, N. Maletic et al., Synchronization in 5G networks: a hybrid Bayesian approach toward clock offset/skew estimation and its impact on localization. J Wireless Com Network 2021, 91 (2021). https://doi. org/10.1186/s13638-021-01963-x

\section{Publisher's Note}

Springer Nature remains neutral with regard to jurisdictional claims in published maps and institutional affiliations.

\section{Submit your manuscript to a SpringerOpen ${ }^{\circ}$ journal and benefit from:}

- Convenient online submission

- Rigorous peer review

- Open access: articles freely available online

- High visibility within the field

- Retaining the copyright to your article

Submit your next manuscript at $>$ springeropen.com 